\title{
Decay Detection in Red Oak Trees Using a Combination of Visual Inspection, Acoustic Testing, and Resistance Microdrilling
}

\author{
Xiping Wang and R. Bruce Allison
}

\begin{abstract}
Arborists are often challenged to identify internal structural defects hidden from view within tree trunks. This article reports the results of a study using a trunk inspection protocol combining visual observation, single-path stress wave testing, acoustic tomography, and resistance microdrilling to detect internal defects. Two century-old red oak (Quercus rubra) trees located in Capitol Park, Madison, Wisconsin, U.S., were visually inspected and then evaluated using a single-path stress wave timer, an acoustic tomography, and a resistance measuring drill. The trees were subsequently felled, and a disk at each test location was obtained and examined. It was found that the visual inspection and single-path stress wave tests correctly identified a general problem but without specificity; the tomograph accurately revealed the general location and magnitude of the defect within the cross-sections tested but required resistance microdrilling to precisely locate defects and differentiate between decay and crackinduced acoustic shadows.

Key Words. Acoustic tomography; crack; decay; hazard tree; resistance microdrilling; Resistograph; risk assessment; stress wave.
\end{abstract}

The science of tree stability analysis uses both biological and engineering principles in attempting to rate a tree's structural soundness and make reasonable predictions of potential for failure. In such analysis, arborists are often challenged by internal structural defects hidden from view within the trunks and roots. Both public safety and urban forest conservation concerns support strong interest in developing and applying more rapid and precise diagnostic techniques to detect decay and other types of structural defects in trees. Visual inspection has been and continues to be the starting point of tree defect evaluation (Matheny and Clark 1994; Mattheck and Breloer 1994; Hayes 2001; Pokorny 2003; Luley 2005). Methods using nondestructive stress waves and minimally invasive resistance microdrilling are now available to evaluate trunk defects hidden from view.

The use of stress waves (ultrasound or soundwaves) to detect decay in trees has been explored by many researchers (McCracken 1985; Mattheck and Bethge 1993; Yamamoto et al. 1998; Wang et al. 2004). The concept of detecting decay using this method is based on the observation that stress wave propagation is sensitive to the presence of degradation in wood. Stress wave velocity is directly related to the physical and mechanical properties of wood. In general terms, stress waves travel slower in decayed or deteriorated wood than sound wood. They also travel around hollows, increasing the transmission time between two testing points. The first-generation stress wave equipment used for decay detection was two-probe systems that measured the wave transmission time in a single path. The capability of a single-path approach for tree decay detection has proven to be limited because stress wave velocity across tree stems varies substantially even for intact trees, and a standard reference velocity for data interpretation is not readily available (Wang et al. 2005).
In recent years, tomography techniques that were developed for engineering or medical applications have been evaluated for their applicability in standing trees. Investigations on urban trees showed a great success of using tomography techniques to detect internal decay. Nicolotti et al. (2003) applied three different types of tomography methods (electric, ultrasonic, and georadar) to urban trees and found different degrees of success. Of the three technologies evaluated, ultrasonic tomography proved to be the most effective tool for detecting internal decay, locating the position of the anomalies and estimating their sizes, shapes, and characteristics in terms of mechanical properties.

Gilbert and Smiley (2004) evaluated an acoustic tomography tool for its ability to quantify decay in white oak (Quercus alba) and hickory (Carya spp.). Picus tomography and visual inspection were used to evaluate 27 cross-sections from 13 trees. Gilbert and Smiley (2004) reported a high correlation between the amount of decay detected by the Picus and the amount actually present in the cross-sections $\left(r^{2}=0.94\right)$ for all cross-sections. The average percentage accuracy for samples in which decay was present was $89 \%$. No cracks were present in the trees they tested.

Both decay and crack are significant structural problems to urban trees, but they have influence on tree stability in different ways. When cracks are present in tested cross-sections, the Picus Q71 operating manual states that tomographs cannot differentiate between decay and crack-induced acoustic shadows (Argus Electronic Gmbh 2006). In those situations, resistance microdrill testing is required to determine the nature of the defect and correctly interpret the tomographs.

Resistance microdrilling measures the relative resistance (drilling torque) of the material as a rotating needle (tip diameter $3 \mathrm{~mm}$ [0.12 in], shaft diameter $1.5 \mathrm{~mm}$ [0.06 in]) is driven into 
the wood at a constant speed. Changes in wood resistance are displayed on a graph as changes in amplitude. Areas of prolonged low resistance indicate decay, cavities, or cracks. Because it requires drilling into the tree, this test is considered minimally invasive.

We report the results of using a combination of visual inspection plus single-path stress wave, acoustic tomography, and resistance microdrilling tools to detect internal defects in centuryold red oak trees.

\section{MATERIALS AND METHODS}

Two red oak (Quercus rubra) trees located at the Capitol Park in Madison, Wisconsin, were evaluated for structural stability in autumn 2005 (Allison 2005). The trees in this study were identified as No. 307 and No. 123. To screen for trunk decay and defects, a visual inspection was conducted looking for anomalies such as fungal conks, cavities, cracks, seams, bulges as well as root-related problems.

Further screening for internal trunk defects using single-path stress wave testing was conducted using a Fakopp Microsecond Timer (Fakopp Enterprise, Agfalva, Hungary). The trunks were tested by aligning the two probes on the trunk in a level northsouth position for the first test and in a level east-west position for a second test. An electronic caliper was used for accurate measurement of the distance between the probes. It took a single arborist less than $15 \mathrm{~min}$ per tree to conduct and record the results of the visual inspection and single-path stress wave screening tests.

Next a Picus Sonic Tomograph tool (Argus Electronic Gmbh, Rostock, Germany) was used to conduct acoustic tomograph measurements on the trees. The Picus Sonic Tomograph measurement system consisted of 12 sensors, which were evenly placed around the trunk in a horizontal plane during testing. Each sensor was magnetically attached to a pin that was tapped into the bark and sapwood. Acoustic wave transmission data were collected by sequentially tapping each pin using the steel hammer. A complete data matrix was obtained through this measurement process at each testing location.

The tomograph measurement was conducted at one elevation of $100 \mathrm{~cm}$ (40 in) aboveground level for tree No. 123 and at three elevations of 10, 100, and $200 \mathrm{~cm}(4,40$, and $80 \mathrm{in})$ aboveground level for tree No. 307. At each elevation, the circumference and distances between sensors were measured using a tape measure and an electronic caliper. This information was used as an input for the system software to map the approximate geometric form of the cross sections. Because the cross-sections of the oak trees tested were irregular, the "free geometry" feature of the program was selected to reconstruct the geometry of the cross-sections. On completion of acoustic measurements, a tomogram was constructed for each cross-section using the Picus Q70 software.

Using information provided by the tomographs regarding the acoustic characteristics of each trunk cross-section, resistance microdrilling was conducted using a F400S Resistograph (IML, Inc., Kennesaw, GA). The drilling paths were selected to enter the area of trunk cross-section displayed in the tomograph as possible decay. The goal was to determine if the tomograph display represented an area of hollow, decay or was a crackinduced acoustic shadow in an area of solid wood.

The trees were felled and a 10 to $15 \mathrm{~cm}$ ( 4 to 6 in) thick disk was cut from each elevation. All the disks were then transported to the USDA Forest Products Laboratory in Madison, Wiscon- sin, for physical examination. A digital picture of the crosssection was also taken for each disk.

\section{RESULTS}

For red oak No. 307, the visual inspection revealed trunk seams, Ganoderma applanatum fungal conks, and lack of root flare. The single-path stress wave tests revealed stress wave transmission times ranging from 1640 to $3248 \mu \mathrm{s} / \mathrm{m}$ (500 to $990 \mu \mathrm{s} / \mathrm{ft}$ ). These values were significantly higher than the anticipated transmission times for intact oak of 621 to $724 \mu \mathrm{s} / \mathrm{m}(189$ to $221 \mu \mathrm{s} / \mathrm{ft}$ ) (Wang et al. 2004). The tomographs indicated a large area of defect at all three elevations. The Resistograph drilling revealed that some areas displayed in the tomographs as potential decay or cavity were actually sound wood and that large cracks were creating an acoustic shadow display in the tomograph.

After being cut down, tree No. 307 was found to have heartwood decay at all three elevations. Laboratory examination confirmed the presence of white rot decaying fungus. The decay was less severe in the upper cross-section (200 cm [80 in] elevation), but it increased in size as the elevation dropped.

In addition to decay, major internal cracks were present in the cross-sections of tree No. 307. The combination of extensive decay and large lateral cracks caused the base disk to fall into several pieces during transportation. The photographs of the disks show that lower and middle cross-sections had multiple lateral cracks and the upper cross-section had one large lateral crack.

Figure 1 shows the comparisons of acoustic tomographs and photographs of the cross-sections at three elevations for red oak No. 307. The dark-colored zones (brown if it is in color print) in the tomograms represent solid wood, and the light-colored zones represent potentially decayed wood (if displayed in color, the tomograms use green, violet, and blue to represent increasing degradation by decay). It is clear that the tomographs show a strong correspondence to the images of the disks. Extensive decay and radiating lateral cracks in the lower and middle crosssections were reflected by large light-color zones in the tomographs. The tomograph of the upper cross-section accurately located the position and orientation of the big lateral crack and heartwood decay.

For red oak No. 123, the visual inspection revealed trunk seams and cracks with cankering on the south side with associated Ustulina deusta fungus. The single-path stress wave tests revealed a stress wave transmission time ranging from 1908 to $2320 \mu \mathrm{s} / \mathrm{m}$ (581 to $707 \mu \mathrm{s} / \mathrm{ft}$ ). The tomography revealed a large area of defect. The Resistograph drilling revealed a large snakeshaped crack. Figure 2 shows the comparison of the acoustic tomograph and photograph of the cross-section for red oak No. 123

\section{DISCUSSION}

The visual inspection in combination with the single-path stress wave testing provided a quick screening to justify the need for more advanced testing. The acoustic tomographs obtained using the Picus Sonic Tomography provided strong evidence of structural defect in both trees. The defect areas identified by the tomographs showed strong correspondence to true physical conditions of the cross-sections. Most decay pockets in the crosssections were well reflected in the tomographs. However, the light-colored potential decay zones shown in the tomographs 


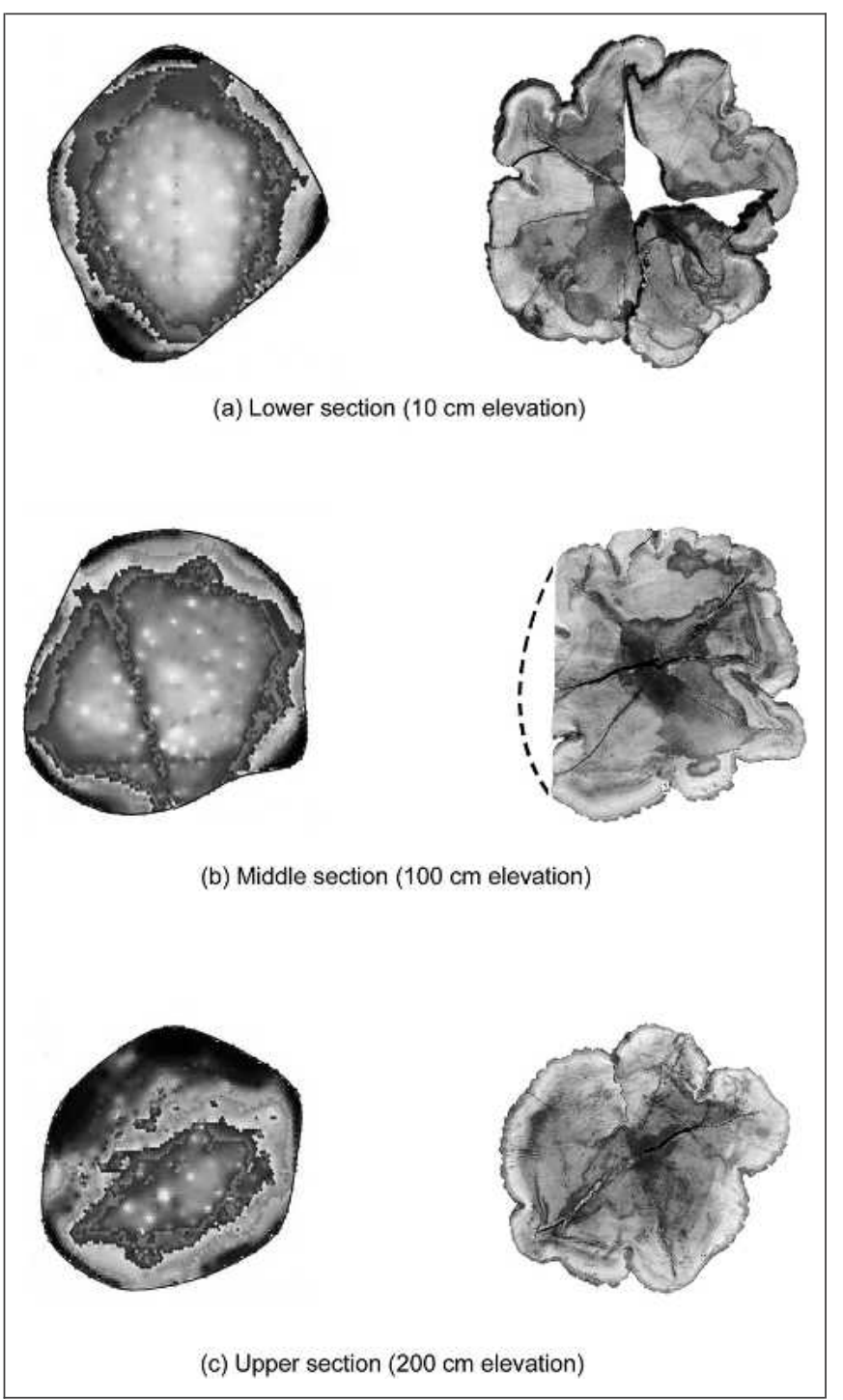

Figure 1. Comparison of acoustic tomographs and photographs of corresponding cross-sections for red oak tree No. 307.

were larger than the true decay areas present in the crosssections. Examination of the cross-sections revealed that internal cracks ("star" crack, "snake" crack, lateral crack, and so on) were also the dominating defects in these two red oak trees. These cracks, mostly present in the radial direction and extended up and down in vertical planes within the trunk, effectively cut off linear propagation of the acoustic waves diverting them to a much longer travel path. The direct result of this was that, even without decay present, the software produced a wide lightcolored zone in the tomographs that resembled the influence of extensive heartwood decay. This observation was consistent with the warning provided in the operating manual (Argus Electronic Gmbh 2006). Tomographs generated using the Picus software were the composite effects of both decay and cracks. Only through carefully directed resistance microdrilling can the tomography displays be interpreted as representing decay versus crack-induced acoustic shadows.

This study of two mature red oaks demonstrates the effectiveness of a trunk decay detection protocol using a combination of

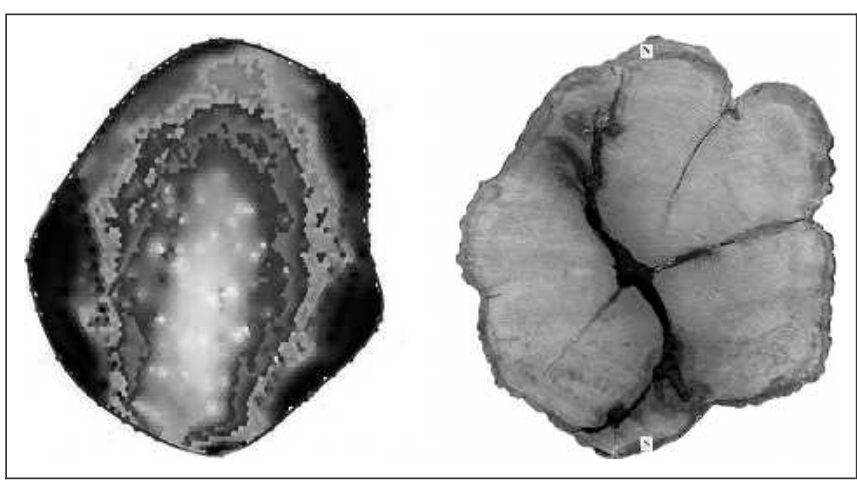

Figure 2. Comparison of acoustic tomograph and photograph of the cross-section for red oak tree No. 123.

visual inspection and single-path stress wave testing to screen for defect followed by acoustic tomography to identify the location and approximate magnitude of defects. Because the tomography only reflects the acoustic properties of the cross-section tested and is not an actual representation of the internal condition, carefully placed resistance microdrilling tests guided by information provided by the tomographs are needed to differentiate between decayed wood and crack-induced acoustic shadows. Laboratory examination of the tested trees confirmed that the screening tests correctly identified a general problem but without specificity, the tomography accurately revealed the general location and magnitude of the defects, but microresistance drilling was required to locate the defects and differentiate between decayed wood and crack-induced acoustic shadows.

\section{LITERATURE CITED}

Allison, R.B. 2005. Capitol Park Tree Structural Stability Study. Final report submitted to Wisconsin Department of Administration, Division of Building and Police, Madison, WI. 308 pp.

Argus Electronic Gmbh. 2006. Picus Sonic Tomograph Manual. Rostock, Germany. 66 pp.

Gilbert, E.A., and E.T. Smiley. 2004. Picus sonic tomography for the quantification of decay in white oak (Quercus alba) and hickory (Carya spp.). Journal of Arboriculture 30:277-280.

Hayes, E. 2001. Evaluating Tree Defects, 2nd ed. Safetrees, Rochester, MN. 34 pp.

Luley, C.L. 2005. Wood Decay Fungi Common to Living Urban Trees in the Northeast and Central United States. Urban Forestry LLC, Naples, NY. 61 pp.

Matheny, N.P., and J.R. Clark. 1994. Evaluation of Hazard Trees in Urban Areas, 2nd ed. International Society of Arboriculture, Savoy, IL. 85 pp.

Mattheck, C.G., and K.A. Bethge. 1993. Detection of decay in trees with the Metriguard Stress Wave Timer. Journal of Arboriculture. 19: 374-378.

Mattheck, C.G., and H. Breloer. 1994. The Body Language of Trees: A Handbook of Failure Analysis. Her Majesty's Stationery Office, London, UK. 240 pp.

McCracken, F.I. 1985. Using sound to detect decay in standing hardwood trees, pp. 281-287. In Proceedings, 5th Symposium on Nondestructive Testing of Wood, 9-11 September 1985. Washington State University, Pullman, WA.

Nicolotti, G., L.V. Socco, R. Martinis, A. Godio, and L. Sambuelli. 2003. Application and comparison of three tomographic techniques for detection of decay in trees. Journal of Arboriculture 29:66-78.

Pokorny, J. 2003. Urban Tree Risks Management: A Community Guide to Program Design and Implementation. NA-TP-03-03. USDA Forest 
Service, Northeastern Area, State and Private Forestry, St. Paul, MN. 194 pp.

Wang, X., F. Divos, C. Pilon, B.K. Brashaw, R.J. Ross, and R.F. Pellerin. 2004. Assessment of decay in standing timber using stress wave timing nondestructive evaluation tools-A guide for use and interpretation. Gen. Tech. Rep. FPL-GTR-147. U.S. Department of Agriculture, Forest Service, Forest Products Laboratory, Madison, WI. 12 pp.

Wang, X., J. Wiedenbeck, R.J. Ross, J.W. Forsman, J.R. Erickson, C. Pilon, and B.K. Brashaw. 2005. Nondestructive Evaluation of Incipient Decay in Hardwood Logs. Res. Pap. FPL-GTR-162. U.S. Department of Agriculture, Forest Service, Forest Products Laboratory, Madison, WI. $11 \mathrm{pp}$.

Yamamoto, K., O. Sulaiman, and R. Hashim. 1998. Nondestructive detection of heart rot on Acacia Mangium trees in Malaysia. Forest Products Journal 48:83-86.

Xiping Wang (corresponding author)

Senior Research Associate

Natural Resources Research Institute

University of Minnesota Duluth

Duluth, MN 55811-1442, U.S.

and

Research General Engineer

USDA Forest Products Laboratory

One Gifford Pinchot Drive

Madison, WI 53726-2398, U.S.

xwang@fs.fed.us

\section{R. Bruce Allison}

Registered Consulting Arborist

Allison Tree Care, Inc.

2800 South Fish Hatchery Road

Fitchburg, WI 53711, U.S.

Résumé. Les arboriculteurs sont souvent mis au défi d'identifier les défauts structuraux internes cachés à la vue et qui sont à l'intérieur des troncs. Cet article traite des résultats d'une étude employant un protocole d'inspection du tronc combinant une observation visuelle, un test de stress par onde directe, une tomographie acoustique et une résistance au micro-forage afin de détecter les défauts internes. Deux chênes rouges
(Quercus rubra) centenaires localisés dans le parc Capitol de Madison au Wisconsin ont été visuellement inspectés puis évalués au moyens des différentes méthodes mentionnées ci haut. Les arbres ont par la suite été abattus et une rondelle a été récoltée de chacune des zones testées au moyen des appareils. On a découvert que l'inspection visuelle ainsi que les tests par onde directe ont correctement identifié un problème général, mais sans pouvoir être spécifique; le tomographe a correctement révélé la localisation exacte ainsi que la magnitude du défaut dans les sections transversales testées, mais cela a requis des tests de résistance par microforage pour localiser précisément ces défauts et pour permettre de différencier la carie des fissures qui induisaient des ombres acoustiques.

Zusammenfassung. Baumpfleger erleben oft die Herausforderung, nicht sichtbare, innere Strukturdefekte in Stämmen identifizieren zu müssen. Dieser Bericht stellt die Ergebnisse einer Studie dar, die ein Stamminspektionsprotokoll, visuelle Ansprache, SchallhammerUntersuchung, akustische Tomographie und Resistograph-Bohrung zur Aufdeckung interner Defekte kombiniert. Im Capitol-Park in Madison, Wisconsin wurden 200jährige Roteichen visuell untersucht, dann mit einem Schallhammer, einem akustischen Tomographen und einem Resistographen untersucht und bewertet. Die Bäume wurden anschließend gefällt und eine Baumscheibe von jedem Testort untersucht. Es kam heraus, dass die visuelle Kontrolle und die Schallhammer-Messung ein generelles Problem korrekt identifizierten ohne es näher zu spezifizieren, während der Tomograph den Defekt akkurat lokalisierte und in der Größe bestimmte, aber es erforderte ein Mikro-Bohren, um den Defekt präzise zu lokalisieren und zwischen Fäule und einem schallverändernden Riss zu unterscheiden.

Resumen. Los arboristas con frecuencia enfrentan el desafío para identificar defectos estructurales internos, escondidos de la vista dentro del tronco de los árboles. Este reporte indica los resultados de un estudio usando el protocolo de inspección al tronco combinado con observación visual, pruebas de ondas de estrés, tomografía acústica y resistencia con micro-taladro para detectar defectos internos. Dos centenarios encinos rojos (Quercus rubra) localizados en Capitol Park, Madison, Wisconsin fueron visualmente inspeccionados, luego evaluados usando un medidor de ondas, un tomógrafo acústico y un taladro de resistencia. Después los árboles se derribaron y una rodaja de cada localidad de prueba fue obtenida y examinada. Se encontró que la inspección visual y las pruebas de onda identificaron correctamente un problema general, sin especificarlo; la tomografía reveló la localización y magnitud del defecto dentro de las secciones trasversales pero requirieron las pruebas de resistencia de micro-taladro para precisar los defectos y las diferencias entre la descomposición y las sombras acústicas. 